\title{
Torrance's future problem-solving instruction: developing students' problem-solving ability
}

\author{
Asanlaya Duangrawa ${ }^{1}$, Prasart Nuangchalerm ${ }^{* 2}$ \\ ${ }^{1,2}$ Faculty of Education, Mahasarakham University, Thailand 44000 \\ *Corresponding Address: prasart.n@msu.ac.th
}

\begin{tabular}{|c|c|}
\hline Article Info & ABSTRACT \\
\hline Article history: & \multirow{4}{*}{$\begin{array}{l}\text { The purpose of this research was to develop the problem-solving ability of } \\
\text { grade } 10^{\text {th }} \text { students by using Torrance's future problem-solving instruction. } \\
\text { The researchers used action research in this study. The target group consisted } \\
\text { of fifteen } 10^{\text {th }} \text {-grade students of the second semester in the } 2019 \text { academic } \\
\text { year. Students who had problem-solving ability scores in low criteria showed } \\
\text { lower than } 70 \% \text { of the full score. This study's research instruments were four } \\
\text { lesson plans in the topic energy, problem-solving ability tests, observation } \\
\text { form of problem-solving ability during lesson plans implementation, and } \\
\text { students' interviewing form in problem-solving ability. Data were collected } \\
\text { and analyzed by descriptive statistics. The finding showed that the problem- } \\
\text { solving ability score of the target group increased in each action cycle. At the } \\
\text { end of the fourth cycle, the problem-solving ability score of all students was } \\
\text { above } 70 \% \text {. According to the results, Torrance's future problem-solving } \\
\text { instructional model can help students improve their problem-solving ability. }\end{array}$} \\
\hline $\begin{array}{l}\text { Received: April } 27^{\text {th }}, 2020 \\
\text { Accepted: August } 18^{\text {th }}, 2020 \\
\text { Published: October } 30,2020\end{array}$ & \\
\hline Keywords: & \\
\hline $\begin{array}{l}\text { Action research; } \\
\text { Instructional practice; } \\
\text { Energy; } \\
\text { Problem-solving ability; } \\
\text { Torrance }\end{array}$ & \\
\hline
\end{tabular}

(C) 2020 Physics Education Department, UIN Raden Intan Lampung, Indonesia.

\section{INTRODUCTION}

In the $21^{\text {st }}$ century, the critical skill of teaching and learning is that students should have the abilities and skills to work and live their lives in a disruptive world (Bedir, 2019; Kadir, 2017; Nuangchalerm, 2017). The purpose of the new era in education should focus on developing students' thinking skills for preparing them to face new problems that may occur in the future. Problem-solving is one of the essential skills and competencies in a world of uncertainty changes (He et al., 2018; Kim et al., 2018; Onsee \& Nunagchalerm, 2019; Saputra et al., 2019). It also requires instructional strategies for making an efficient knowledge acquisition about unknown situations, and it also needs creative application of the knowledge available (Csapó \& Funke, 2017). Therefore, the problem-solving ability is an essential ability that allows students to solve, assess, and find solutions for the complex problem in real life (Perrt et al., 2019; Rokhmat et al., 2019; Rudolph et al., 2018).

The goal of education is not to focus on national or international competitions. The science education paradigm should prepare our students to face uncertainty and more complicated situations (Orth et al., 2018). The problem solving and how do we teach our students to comprehend and manipulate the problem by the right answer and appropriate way to do which we have to implement. It is an acceptable idea to employ suitable instructional practices to lead our students in problem-solving ability (Sweller, 2019). This ability can change learning behavior and scientific literacy to be in advance. It helps students to live and learn modern life activities based on the way of and way in science (Ceberio et.al, 2016; Listiana 
et.al, 2019; Prachagool \& Nuangchalerm, 2019)

There are different and variety of pedagogy or instructional models that can improve students' competencies and problem-solving. The famous one instructional practice is the Future ProblemSolving Program International Program or FPSPI, an international educational program founded in 1974 by Dr. Paul Torrance. The foundation was creative problem solving and the futurist thinking model. The instruction can help students improve their critical thinking and problem-solving skills to changing world and hypothetical future situations (Azevedo et al., 2019; Main et al., 2019; Treffinger et al., 2012). Torrance's future problem-solving instructional model was developed to motivate youth to realize future problems and improve thinking processes (Adair, 2019).

The instructional practice in science may not be recitation in contents, but also the thinking process and necessary learning skills should be embedded in the curriculum. So, this study aims to develop the problemsolving ability of grade 10 students. They are studying physics; it seems to be difficult but interested in their modern life. Action research is employed to gain their ability as well as physics achievement should be promoted. Torrance's future problem-solving instructional model is chosen to help them reach physics learning; the thinking process is concurrently developed through instructional practices.

\section{METHODS}

The focus of this action research was to improve the problem-solving ability of grade $10^{\text {th }}$ students. The study was conducted in the second semester, the academic year of 2019. More details will be described in the following.

\section{Participants}

Initially, the study participants were grade $10^{\text {th }}$ students from one classroom in a high school located in the northeast of Thailand.
The purposive sampling was employed for selecting participants. Students were screened through the preliminary problemsolving test. The result illustrated that fifteen students could not reach the criteria in $70 \%$ of problem-solving ability scores. Therefore, fifteen students who got problem-solving ability scores under $70 \%$ were the target group in this study.

\section{Research Instruments}

This study's research instruments consisted of a lesson plan based on Torrance's Future Problem-Solving instruction in the topic of energy, a problemsolving ability test, an observation form, and an interview form. Action research accepts reliable research instruments by expert judgments. Most validity and reliability were provided in terms of qualitative comments.

Lesson plan: Four lesson plans for Torrance's Future Problem-Solving instruction with 8 hours in energy and physics for students were constructed. The first lesson plan was implemented in cycle one that spent 2 hours on renewable energy topics. Secondly, in cycle 2, implement one lesson plan on photovoltaic topics. Cycles 3 and 4 used two other lesson plans on nuclear energy and technology. Each lesson plan was corrected and checked for its appropriateness by five experts. Then improving lesson plans using expert guidance as reliability.

Problem-solving ability test: Writing test with one situation with six questions of problem-solving processes that employed Torrance (1974). The test consisted of 6 processes, including identifying problems, selecting the underlying problem, generating solution ideas, developing criteria to evaluate their solution ideas, evaluating all solutions to determine the best one, and developing an action plan. The constructed test was checked and developed using the Index of itemobjective congruence by five experts.

Observation form: It was an observation form about students' problem-solving ability as individuals that consisted of three levels. The instrument was built and checked by five 
experts. Then developed it before implementing it to the target students.

Interviewing form: The open-ended interview has questions about problemsolving ability. Five experts corrected each question to be revised before the implementation.

\section{Data Collection and Analysis}

This research was classroom action research employed by Kemmis et al. (2013). Data collection consisted of 4 steps: plan, act, observe and reflect implemented in fourcycle. More details can be described in the following (Figure 1).

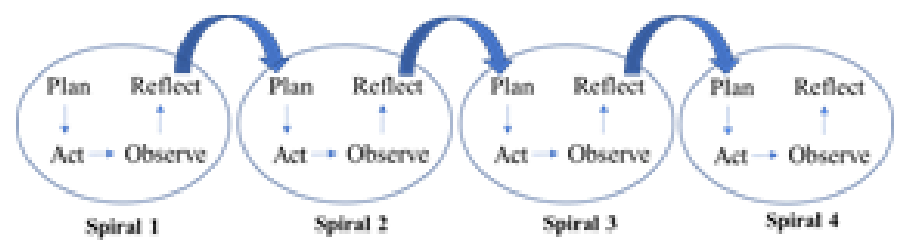

Figure 1. Steps of action research

Plan: Start with surveying students' contexts and problems by observing the learning atmosphere and their behavior while studying. Then document analysis, which is related to problem-solving ability and Torrance's future problem-solving instructional model, is analyzed. Consequently, research instruments were created and developed.

Act: After constructing and improving the research instruments, lesson plans 1,2,3, and 4 were used in cycles $1,2,3$, and 4 to implement them to the target students.

Observe: Researchers observed problemsolving ability behaviors of students through observation form. After class, problemsolving ability tests were investigated. Also, some target students were interviewed about problem-solving ability randomly.

Reflect: Data were concluded from testing, observation, and interviewing. Results were examined to answer the purpose of this study. Information and findings from observation and interviewing target students reflected problems in the teaching and learning process. Then, researchers find the guidelines for solving problems in the next cycle.

\section{RESULTS AND DISCUSSION}

The target students were Identified and selected in terms of problem-solving ability using the test before implementing them with pedagogy using Torrance's future problem solving instructional model. Fifteen students who did not pass $70 \%$ of the problem-solving ability score participated in this study. The purpose of the research was to develop students' problem-solving ability scores to pass $70 \%$. After target students learned through Torrance's future problem solving instructional model, the results have shown in table 1

Table 1. Number of students who have problemsolving ability score above and under $70 \%$ in each cycle

\begin{tabular}{ccc}
\hline \multirow{2}{*}{ Cycle } & \multicolumn{2}{c}{ Number of Students } \\
\cline { 2 - 3 } & Pass $70 \%$ & Lower than $70 \%$ \\
\hline 1 & 3 & 12 \\
2 & 7 & 8 \\
3 & 13 & 2 \\
4 & 15 & 0 \\
\hline
\end{tabular}

From table 1, the data has shown that the number of students who have problemsolving ability scores over $70 \%$ of total scores after using Torrance's future problemsolving instructional model in cycle 1 was three students or $20 \%$ of all students. In cycle 2 and 3, students who pass $70 \%$ of problemsolving ability increase to 7 and 13 persons or $46.67 \%$ and $86.67 \%$ of all students. After learning implemented in cycle four, the data revealed that all students had passed $70 \%$ of problem-solving ability. Each component of problem-solving can be shown in (1) identifying problems, (2) selecting the 
underlying problem, (3) generating solution ideas, (4) developing criteria to evaluate their solution ideas, (5) evaluating all solutions to determine the best one, and (6) developing an action plan. Furthermore, the detailed results of each cycle can be described in the following cycle and figures.

\section{Cycle 1}

Researchers have observed the problemsolving ability of students in class during implemented pedagogy. The qualitative data can be summarized in the following. Most students cannot identify various problems from situations given and impart clear reasons for selecting the underlying problem. They cannot offer diverse solution ideas to solve the problem and cannot evaluate the solution. Their selected solution ideas are rarely not on point with the underlying problem.

From observation, researchers can conclude that most students have trouble offering problems and solution ideas that are not varied. Also, they do not understand the criteria for evaluating the solution ideas that cannot select the best appropriate solution for the problem situation. After Torrance's future problem-solving instructional model was implemented, three students have passed $70 \%$ of problem-solving ability. The result has shown in Figure 2

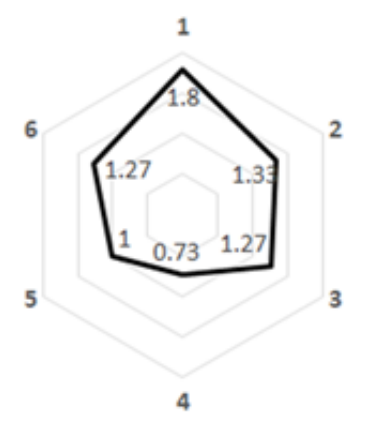

Figure 2. The problem-solving ability in cycle 1

\section{Cycle 2}

Researchers have observed the problemsolving ability of students during the pedagogy implementation. The qualitative data can be summarized in the following. Many students can identify various problems from the situation given, while some students cannot impart the necessary reasons to support the decision to select the underlying problem. The majority of students can offer their solution ideas to solve the problem, but the solution's processes are unclear. They also cannot impart the various criteria for evaluating the solution. Moreover, most of them cannot evaluate their solution ideas for selecting the best one that suits the situation. They cannot present their action plan.

Researchers also interviewed the students who did not pass $70 \%$ of problem-solving ability after finishing the test in cycle 2 . The qualitative data can be summarized in an impressive view below.

Q1: How to do it if you have to offer solution ideas?

“... Sometimes I will imagine the situation given that problems happen in real life and then I will look for the easy way to solve the problem."

(Student A, January 2020)

“... I think that every problem in the world can be solved by ourselves. It should start with the conscience of humans."

(Student B, January 2020) Q2: How to do it if you have to evaluate your solution ideas for selecting the best one?

“... I will review the advantages and disadvantages of each solution and choose the best solution that has many advantages."

(Student C, January 2020)

“... I will choose the best solution idea from the method that we make sure to do. Because some solutions are rarely possible to solve. It is too difficult to make it happen in the present."

(Student D, January 2020)

From observations and interviews, researchers can conclude that most students have trouble with offering transparent processes of solution ideas. They still have trouble developing various criteria for evaluating the solution ideas that make them unable to decide the best appropriate solution to the problem situation. After Torrance's future problem-solving instructional model implemented in cycle 2 , students who pass 
$70 \%$ of problem-solving ability increase to 7 students. The result has shown in Figure 3

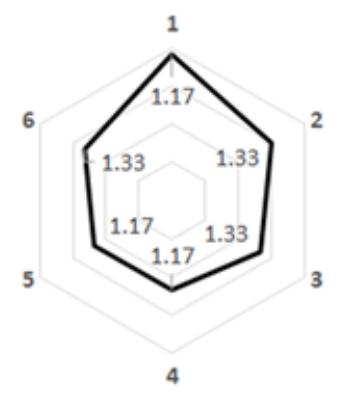

Figure 3. The problem-solving ability in cycle 2

\section{Cycle 3}

The qualitative data can be summarized as follows. All students can identify various problems from the situation given, and most of them can select the underlying problem with clear reasons to support the decision. They also can offer diverse solution ideas to solve the problem and impart the solution method. Some students can not impart the various criteria for evaluating the solution. For evaluating their solution ideas, Some students can select the appropriate solution. However, Someone can not choose the solution that suits the problem situation and still present an unclear action plan.

From observations, researchers can conclude that some students still have trouble developing various criteria for evaluating their solution ideas and selecting the best appropriate solution to the problem situation. Furthermore, some students have a problem with writing and presenting their action plans that make it unclear for the processes to solve their underlying problem. After Torrance's future problem solving instructional model implemented in cycle 3 , students who pass $70 \%$ of problem-solving ability increase to 13 students. The results have shown in Figure 4.

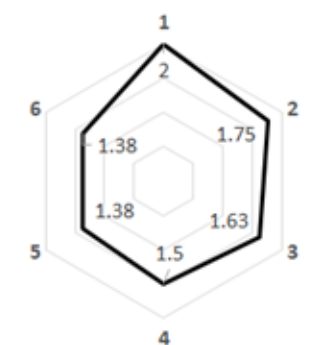

Figure 4. The problem-solving ability in cycle 3

\section{Cycle 4}

In this cycle, all students can identify various problems from the given situation, impart supporting reasons to select the underlying problem, and offer solution methods and various solution ideas to solve the problem. Students can also impart the various criteria for evaluating the solution and evaluate their solution ideas to select the appropriate solution with a problem situation and present their action plan.

From observations, researchers can conclude that most students gain problemsolving abilities. However, a minority of students still have difficulty developing various criteria for evaluating and selecting the best appropriate solution to the problem situation. Most of them have developed in their action plans presentation. After Torrance's future problem-solving instructional model implemented in cycle 4 showed, all target students pass $70 \%$ of problem-solving ability. The result has shown in figure 5 .

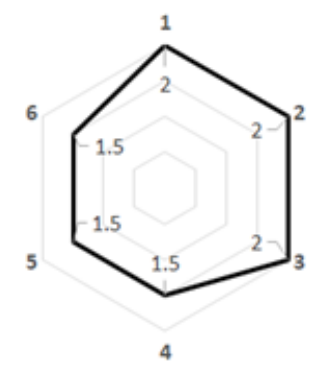

Figure 5. The problem-solving ability in cycle 4

The results indicated that Torrance's future problem-solving instructional model could help students increase their problemsolving ability, especially in identifying the various problems, selecting the underlying problem, and generating solution ideas to solve their problem (McCaffrey, 2018; Main et al., 2019). They can develop and design action plans for solving their problem. Pedagogy emphasizes brainstorming and teamwork activity that plays a vital role in improving thinking skill and help to make a problem-solving skill in students (Gvozdic \& Sander, 2018). Also, the learning activity in class helps students share their own opinions 
with their group, which tends to help students improve their thinking by accepting other opinions (Rosen, 2017).

\section{CONCLUSION}

Torrance's future problem-solving instruction help students passed $70 \%$ of problem-solving ability. Most students have trouble with identifying problems and offering solution ideas are not variety. They cannot generate the criteria for evaluating their solution ideas and select the best appropriate solution for the problem situation. In cycle 2 , students who passed $70 \%$ of problem-solving ability increased to 7 students. Most students have trouble offering transparent solution ideas and developing various criteria for evaluating their solution ideas. They cannot decide the best appropriate solution to their problem. In cycle 3, students who passed $70 \%$ of problem-solving ability gain to 13 students. Student majorities have the problem-solving ability in the right criteria that may cause students to be familiar with teamwork activity and collaboration. It allows them to share their ideas and knowledge and discuss the situation problems together. In cycle 4, fifteen students whose target students in this research can pass $70 \%$ of problem-solving ability. According to the results, Torrance's future problem-solving instructional model can help students improve their problemsolving ability.

\section{ACKNOWLEDGEMENT}

We have sincerely appreciated the Institute for the Promotion of Teaching Science and Technology (IPST) for financial support and provide learning opportunities during the study.

\section{AUTHOR CONTRIBUTIONS}

$\mathrm{AD}$ and $\mathrm{PN}$ wrote the manuscript, collected, and analyzed data. PN conceptualizing and reviewing literature. AD display data.

\section{REFERENCES}

Adair, J. (2019). Decision making and problem solving: Breakthrough barriers and banish uncertainty at work. Kogan Page Publishers.

Azevedo, I., de Fátima Morais, M., \& Martins, F. (2019). The future problem-solving program international: An intervention to promote creative skills in Portuguese adolescents. The Journal of Creative Behavior, 53(3), 263-273.

Bedir, H. (2019). Pre-service ELT teachers' beliefs and perceptions on $21^{\text {st }}$ century learning and innovation skills (4Cs). Journal of Language and Linguistic Studies. 15(1), 231-246.

Ceberio, M, Almudi, J. M., \& Franco, A. (2016). Design and application of interactive simulations in problemsolving in university-level physics education. Journal of Science Education and Technology, 25(4), 590609.

Csapó, B., \& Funke, J. (eds.) (2017). The nature of problem solving: Using research to inspire 21st-century learning. OECD Publishing, Paris.

Gvozdic, K., \& Sander, E. (2018). When intuitive conceptions overshadow pedagogical content knowledge: Teachers' conceptions of students' arithmetic word problem solving strategies. Educational Studies in Mathematics, 98(2), 157-175.

He, Y., Du, X., Toft, E., Zhang X., Qu, B., Shi, J., \& Zhang, H. (2018). A comparison between the effectiveness of PBL and LBL on improving problem-solving abilities of medical students using questioning, Innovations in Education and Teaching International, 55(1), 44-54.

Kadir, M. A. A. (2017). What teacher knowledge matters in effectively developing critical thinkers in the $21 \mathrm{st}$ century curriculum?. Thinking Skills and Creativity, 23(1), 79-90 
Kemmis, S., McTaggart, R., \& Nixon, R. (2013). The action research planner: Doing critical participatory action research. Springer Science \& Business Media.

Kim, J. Y., Choi, D. S., Sung, C. S., \& Park, J. Y. (2018). The role of problem solving ability in innovative behavior and opportunity recognition in university students. Journal of Open Innovation: Technology, Market, and Complexity, 4(1), 1-13

Listiana, L., Abdurrahman, A., Suyatna, A., \& Nuangchalerm, P. (2019). The effect of Newtonian dynamics STEMintegrated learning strategy to increase scientific literacy of senior high school students. Jurnal Ilmiah Pendidikan Fisika Al-Biruni, 8(1), 43-52.

Main, L. F., Delcourt, M. A., \& Treffinger, D. J. (2019). Effects of group training in problem-solving style on future problem-solving performance. The journal of creative behavior, 53(3), 274-285.

McCaffrey, T. (2018). A visual representation to quantitate, diagnose, and improve creativity in insight problem solving. The Journal of Creative Behavior, 52(1), 52-65.

Nuangchalerm, P. (2017). Preservice teachers' twenty first century learning skills: Three different majors of study. International Journal of Advanced and Applied Sciences, 4(7), 124-128.

Onsee, P., \& Nuangchalerm, P. (2019). Developing critical thinking of grade 10 students through inquiry-based STEM learning. Jurnal Penelitian dan Pembelajaran IPA, 5(2), 132-141.

Orth, D., Davids, K., \& Seifert, L. (2018). Constraints representing a meta-stable régime facilitate exploration during practice and transfer of learning in a complex multi-articular task. Human Movement Science, 57, 291-302.

Perrt, J. D., Erukhimova, T. L., \& Bassichis, W.H. (2019). New video resource for calculus-based introductory physics, design and assessment. I. Electricity and magnetism. American Journal of Physics, 87(5), 335-340.

Prachagool, V., \& Nuangchalerm, P. (2019). Investigating understanding the nature of science. International Journal of Evaluation and Research in Education, 8(4), 719-725.

Rokhmat, J., Marzuki, Wahyudi, \& Putrie, S. D. (2019). A strategy of scaffolding development to increase students' problem-solving abilities: The case of physics learning with causaliticthingking approach. Journal of Turkish Science Education, 16(4), 569-579.

Rosen, Y. (2017). Assessing students in human-to-agent settings to inform collaborative problem-solving learning. Journal of Educational Measurement, 54(1), 36-53.

Rudolph, J., Greiff, S., Strobel, A., \& Preckel, F. (2018). Understanding the link between need for cognition and complex problem solving. Contemporary Educational Psychology, 55, 53-62.

Saputra, A. T., Jumadi, J., Paramitha, D. W., \& Sarah, S. (2019). Problem-solving approach in multiple representations of qualitative and quantitative problems in kinematics motion. Jurnal Ilmiah Pendidikan Fisika Al-Biruni, 8(1), 8998.

Sweller, J. (2019). Human problem solving and instructional design. In Problem Solving for Teaching and Learning (pp. 25-33). Routledge.

Torrance, P. E. (1974). Gifted for children in the classroom. Macmillan.

Treffinger, D. J., Solomon, M., \& Woythal, D. (2012). Four decades of creative vision: Insights from an evaluation of the future problem solving program international (FPSPI). Journal of Creative Behavior, 46(3), 209-219. 